\title{
Four companies announce discovery of $\beta$-secretase gene
}

Between late September and early December, four companies independently reported the discovery of the gene encoding $\beta$-secretase, a long-sought protease believed to be pivotal in the pathology of Alzheimer disease. Each arrived at the gene sequence through a different experimental strategy, and it is notable that all four discoveries were made by companies able to draw on substantive resources available to the private sector. Although SmithKline Beecham has an apparent lead in patent position, industry analysts warn against early speculation on the likely winner of the race for a clinically efficacious inhibitor.

The search for $\beta$-secretase was instigated five years ago, on the realization that amyloid precursor protein is cleaved by three enzymes, the $\alpha-, \beta$-, and $\gamma$-secretases. The joint action of the $\beta$ - and $\gamma$-secretases generates amyloid $\beta$-peptide $(A \beta)$, the protein that makes up the plaques dotting the brains of people with Alzheimer disease, and believed to cause dementia. The search intensified with the discovery that early-onset familial Alzheimer disease is caused by mutation of the gene encoding amyloid precursor protein. All of the groups exploited cell lines carrying the so-called Swedish mutation (which accelerates the rate at which $A \beta$ is produced) to identify $\beta$-secretase.

SmithKline Beecham (King of Prussia, PA) kicked off the flurry of publications by submitting abstracts to the eighth International Aspartic Proteinase conference (Madeira, Portugal; September 7-11) and the annual meeting of the Society for Neuroscience (Miami, FL; October 23-28). Ishrut Hussain and colleagues obtained the partial cDNA sequence of an aspartyl protease from a proprietary database, used it to pull out a fulllength cDNA from a melanoma cell line, and found that transfecting it into a cell line triggered an increase in $\mathrm{A} \beta$ production ( $\mathrm{Mol}$. Cell. Neurosci. 14, 419-427; 1999).

In contrast, researchers at Amgen (Thousand Oaks, CA) used a high-throughput assay to identify clones that modulate $A \beta$ production by a cell line carrying the Swedish mutation (Science 286, 735-741; 1999).

Meanwhile, Mark Gurney and colleagues at Pharmacia \& Upjohn (Kalamazoo, MI) searched a public database of predicted proteins of Caenorhabiditis elegans for aspartyl proteases, and using these, obtained human orthologs. The diminution of $A \beta$ production

Bette Phimister is Associate Editor of Nature Genetics. by transfecting cell lines with antisense constructs implicated $\beta$-secretase (which they call Asp2; Nature 402, 533-537; 1999).

Elan Pharmaceuticals adopted a biochemical approach; using an inhibitor to purify the protein, they sequenced its $\mathrm{N}$ terminus, which granted a handle on the gene sequence (Nature 402, 537-540; 1999).

The fact that four parties have independently identified the same protein and demonstrated it to have $\beta$-secretase activity leaves little doubt that a plausible target is now in hand. The extent to which it is a realistic target for therapy, however, is another issue; two characteristics of the $\beta$-secretase may render its inhibition a challenge. First, it resides within an intracellular vesicle, which means that an inhibitor must traverse two lipid membranes-not to mention the blood-brain barrier-to reach its catalytic domain. Second, it is widely expressed and may be critical to cellular and systemic welfare.

These hurdles have not, it seems, dinted the optimism and drive of those representing interested companies, which are doubtless inspired by an estimated market of \$2 billion in 2003 (SG Cowen Securities Corp; New York).

Thomas Meek (SmithKline Beecham) suggests that anyone who has carried out substantive investigations on inhibiting HIV protease or renin - which, he says, are likely to be similar in structure to $\beta$-secretase-will have collections of inhibitors that may inhibit, or be amenable to inhibiting, $\beta$-secretase. (Companies who have done so include Abbott, Glaxo Wellcome, Hoffman LaRoche, Merck, SmithKline Beecham, and Pharmacia \& Upjohn.) This, he says places SmithKline Beecham and Pharmacia \& Upjohn (of the four companies who have made public their knowledge of $\beta$-secretase identity) in a good position to identify effective inhibitors from their existing compound collections-although he acknowledges that Amgen and Elan could supplement their collections of potential inhibitors through partnership or other means.

Eric Schmidt, analyst at SG Cowen, believes it's ridiculous to speculate at this stage and notes that not only does Amgen have some excellent chemists, but Elan has had success with small-molecule drugs, and in this regard, "biotechnology companies have beaten pharmaceuticals at their own game." Similarly, Richard van den Broek, analyst at Hambrecht \& Quist (New York), believes that speculation is premature, and suggests that "commoditorial chemistry" may be a more fitting term for "combinatorial chemistry."

As for proprietary positions, SmithKline Beecham is the only one of the four companies willing to confirm that it has applied for patents on the gene and protein sequences - in the context of treating Alzheimer disease-in the US, Europe, and other countries (the patent was filed on January 28, 1997). Rudolph Tanzi, who researches Alzheimer disease at the Massachusetts General Hospital, speculates that SmithKline Beecham "may well have beat everyone [to the target]," although he notes that Elan has focused on it for much longer.

Allen Roses, vice president and worldwide director of genetics at Glaxo Wellcome (Research Triangle Park, NC), says that "at the end of the day, it [patent protection] ain't going to make a difference until there is a pill to treat or prevent the disease; that is when we will see billion-dollar infringement lawsuits and disputes settled out of court."

Bette Phimister

\section{Japan creeps toward proteomics}

Proteomics is at last making an appearance on Japan's national agenda: For the first time, protein-related research has been targeted by the government-in its most recent supplementary budget (unveiled last November), and in the requested budget for fiscal year 2000, which begins this April. A new nuclear magnetic resonance (NMR) facility for largescale analysis of protein function and structure is due to open this year, and several institutes coming to the end of their fixed-term genomics programs are hoping to gain a new lease on life by shifting over to proteomics. However, some criticize the fragmented and reactive approach of the government ministries to proteomics research, and say an integrated effort involving relevant government ministries, industry, and academia is needed if Japan is to be globally competitive in this area.

"There has been a significant shift in the [government's] attitude towards proteinrelated research," says Reiro Shimura, director of the Biomolecular Engineering Research Institute (BERI; Osaka). Shimura says that gaining support for such research has been "extremely difficult" until very recently. "The government is preoccupied with genome and SNPs [single-nucleotide 